\title{
The Dynamics of Canal Colonies; Agricultural Development and Socio-Political Change in British Multan
}

\author{
Sajjad Akhter \\ Department of Pakistan Studies, \\ Bahauddin Zakariya University, Multan \\ akhterbzu@gmail.com \\ Basit Nadeem \\ Lecturer \\ Department of Geography \\ Bahauddin Zakariya University, Multan \\ Basitnadeem2249@yahoo.com
}

\begin{abstract}
Punjab was the last province which annexed with British India in 1949.British implemented many reforms in subcontinent, but Canal Colonies were excellent irrigation system introduced by the British, especially in the south west part of the Punjab province. These canal colonies proved very useful for the agriculture sector which boost up the not only the economic condition of the native people of the colonies areas but also increase revenue collection of the British government in India. Canal Colonies changed the arid/ barren land of the southern district of the province into a fertile land. British government also achieved their objectives through canal colonies. Therefore, government allotted the land of the canal colonies in different categories and rewarded some specific classes in native communities of the canal colonies. In canal colonies government reserved huge piece of land for their military objective because Indian Military was necessary for the strong law and order in British India and their strong influence in Middle East and other parts of the world. These canal colonies bring an agriculture revolution in the province which change the socio-economic condition of the people of the native districts. In Multan three major canal colonies were introduced, Sidhnai, Lower Bari Doab and Nili Bar canal
\end{abstract}


colony. In these canal colonies British government also implemented same polices like the previous canal colonies of the province. Therefore, the in Multan district landed elites were loyal and cooperative with government with their wealth and men. These landed elites played important role at political canvas of the province during British rule in Multan.

Keywords: canal colonies, agriculture, landed elites, social and political change.

The south western region of Punjab province was received short rainfall during whole year. The rainfall is very vital for agriculture especially for the arid and barren land. The farmers were mostly used well irrigation and inundation canal irrigation system of this region. Well irrigation system was costly and insufficient for the agriculture need of the farmers of Multan region. Inundation canals were seasonal canals; these canals were mostly operational during the flood season in summer. The people of the south western region of the Punjab province were mostly lived nomadic life in the rural areas of Multan region. Therefore, British government introduced excellent canal system in the province and Multan region as well. In 1849 Punjab province annexed with British, at that time only twenty-five percent of the total land of the province was under cultivation and approximately one sixth percent of the cultivated land was irrigated with canal water. (Himadri, 1982) British government decided to use barren land of Punjab province under cultivation therefore government decided to use canal water for irrigation. The British government introduced excellent canal system in Punjab province. The government excavated new canal in different regions of the province and extended the old canals. The government also decided to utilized others means of irrigation; tanks private canal and wells. All these developments were made to increased productions of agriculture and to use more arid/barren land under cultivation. 
It was the desires wish of the British to enhance the agriculture production because firstly it was used as raw material for industry of United Kingdom secondly it was one of the main sources of revenue for the British government. The British also introduced canal colonies in all over the Punjab province. Canal colonies brought agricultural revolution in the province which helps out to change the socio economic position of the people of the province and Multan region as well. All these developments produced a new class of people in the canal colonies areas who were not only cooperate with British government but also play important role at political canvas of the Punjab province.

The south western region of Punjab province and specially the Multan district is/was primarily an agricultural. Before British rule canals were also existed in Multan but these condition were no good and most of them were inundation canals. These canals were insufficient for the agricultural requirement. After taking over the control of the Punjab, British established a strong administration system and conducted survey about cultivated land and agriculture revenue. Soon they realize to introduced canal irrigation system in the province which help out them to increase the proportion of cultivated land and to enhance agriculture revenue. British also wanted to produce new loyal class of people in the province who has soft corner for them. Therefore, they started excellent canals irrigation system with accompanied by the colonization of those lands by immigrants from other parts of Punjab. A new term "the Punjab canal colonies" is used for the society that emerged in the new canal irrigation region. British were introduced total nine canal colonies in the province from 1890-1940. These canal were The Sidhnai, Sohag Para, Chunian, upper Chenab, upper Jehlum, the Lower Chenab, the Lower Jehlum, the Lower Bari Doab and the Nilli Bar. (Ali, 1979) In the context of British Rule the establishment of canal colonies was one of the best forms of British interest in the agricultural economy in the British India. British could have used land ownership of the canal colony areas to improve the 
socio economic position of the agriculture class and also create new landholding political class. At large number area were being under cultivated and irrigated through canals between 1885-1940 that were increased from thirty lakhs acres to one crore and thirty-five lakh acres. (Ali, 1989) At this large number of increase in canal irrigation in canal colony areas saw huge extension in the agriculture development which were the main source of socio economic development during the British rule in sub-continent. British controlled the canal system and the water resources of canal colonies. The proprietorship of both land and water gave government strong control over the agricultural production thus its increased the political and economic power of the British. Each canal colony had its own policy of land distribution on the basis land were allotted to the selected grantees. The Sidhnai, the Lower Bari Doab and the Nilli Bar matured the soil of Multan district. The Sidhnai canal was perennial canal and its irrigated land only in kharif crops while rabi crop are matured by well. The Lower Bari Doab and the Nilli Bar irrigated the land for the whole year. The Nilli Bar canal colony was the part of the Sutlej Valley Project, it also matured the land of princely states of Bahawal Pur and Bikaner.

\section{The Sidhnai Colony}

The Sidhnai Colony was the first canal colony which is situated in the Multan district, it was mainly colonized in three different phases between 1886 to 1897 . Approximately two lakhs and twenty-five acres' land were allotted between the different categories to the people of Punjab. But it was conceded that a certain limit of land was fixed for people of Multan district. British government mostly allotted the land in those families who have already possessed agriculture land in the districts of the upper Punjab. (Ali, 1989) British government believed that both the development of agriculture and political order could be best to strength the land holding class in the province. Lord Curzon appointed 
irrigation commission in 1901. This commission had revenue and irrigation experts visited the whole country and submitted its report in 1903. The excellent irrigation work started at the recommendations of irrigation commission was the Triple Canal Project, this project made possible to construct the Lower Bari Doab canals. The main objectives of the Triple Canal Project were to irrigate soil of the Ganji Bar in the watershed between the rivers Ravi and the Sutlej. The whole Triple Canal Project was completed in March,1917, at a total expenditure of 10.1 crores acres. This project irrigated 1.02 crores land in 1920-21 and after the opening Sutlej Valley Project canals irrigated total area reached 1.22 crores and in 1938-39 it was 1.31 crores acres. (Administration Report of the P.W.D (irrigation branch), 1938-39)

\section{Lower Bari Doab Colony}

Construction work of Lower Bari Doab Colony started in 1907-08 and first time it was open for irrigation in April 1913. This colony situated in Montgomery tehsil of the Montgomery district and Khanewal tehsil of the Multan district. In Lower Bari Doab Colony settlement proceedings started in 1914. (Saini, 1975) In Lower Doab Colony unique and different methods of land allotment scheme had introduced it was different to the earlier canal colonies of the province. This colony had large area to be colonized during the first quarter of the twentieth century. It reflected a variety of trends in administrative thinking and became the focus of a number of socio-economic and political needs of the British. British Government also used the land of the Lower Bari Doab Colony for their military purposes, they allotted land for horse breeding and land grants to military personnel. A large percentage of land were reserved for the indigenous people for the landed gentry and open auctions for the people of previous colonies. In addition, land was reserved for the special objects which contains horse run for cavalry regiments and some grants for agricultural improvements. The British Government started sanctioned for the 
colonization scheme for the Lower Bari Doab in 1914 and demanded the allotment of 11,92,000 acres. (Ali, 1989) Even the Lower Bari Doab was not dominant colonization as in Jehlum Colony but horse breeding remained leading portion of this colony. Statistic of total allotment of land in the Lower Bari Doab are shown in the below table.

ALLOTMENT OF LAND IN THE LOWER BARI DOAB

\begin{tabular}{|l|l|l|}
\hline Type of Grant & $\begin{array}{l}\text { Original } \\
\text { allocation acres }\end{array}$ & $\begin{array}{l}\text { Percentage of total } \\
\text { allotted land }\end{array}$ \\
\hline $\begin{array}{l}\text { Land for sale by } \\
\text { auction }\end{array}$ & 125,000 & 7.83 \\
\hline Regimental farms & 100,500 & 9.81 \\
\hline Horse Breeding & 509,500 & 45.67 \\
\hline War Veterans & 180,000 & 11.25 \\
\hline Agriculturists & 110,000 & 11.74 \\
\hline Rewards & 22,00 & 1.13 \\
\hline Landed Gentry & 75,000 & 6.77 \\
\hline
\end{tabular}

Source; Imran Ali, (1989). The Punjab Under Imperialism,18851947.

Military grantees and war veterans were second largest group for land grantees in the Lower Bari Doab colony. With the outbreeak of $1^{\text {st }}$ World War the land for military grantees was increased by 75000 acreas. Infact the increas of land to the war granttes were the reward by the British government in the services of first World War. This was the most important feature of the Lower Doab Colony that a large portion of land alloted to the military personels. This was the fact that the Punjab province contribute more men than any other part of the British India army.

The war veterans when came back in different parts of British India they plated very useful role in society. These people demanded that government should be introduced new constitutional reform, modern education, and political reforms for the local community. As show in the above table British government also reserved a handsome share of land for the civilian people of the province such as agriculture class and landed gentry of the estern district of the Punjab. The government also designed some further grants other than military grants for the political and development purpose, all 
these grants have motivation factors behind it. British government reserved fifteen thousand acres for cattle breeding to encourage the livestock industory and to change the socio-economic positions of the people. For the development of agriculture sector British government allotted land to the agriculture experts for the supply of new seeds and to encourage the cultivation of upgraded varieties of cotton. For this purpose, 3000 acres allotted to the European Cotton expert H.T. Conville and 7220 acres to British Cotton Growing Association. This was the largest grant allotted to a metropolitan commercial organization in the canal colonies. (Ali, 1989)

The British government also fixed a special grant for the landed elites, this types of grants had political motivation behind it. Government reserved 60,000 acres for the rural landed families. This was the first time that a large number canal colony areas were reserved for landed elite class in Punjab province. This special grant was allotted to those influential families that had retained their influence and respect in the rural community of the province. These landed elite played very vibrant role in socio-economic and political development after constitutional reforms of 1919. Unionist Political Party was the group of these landed elites, this party comprehensively rule in the Punjab province from 1922-1945. (Yadav, 1987) This colony has a grant for the lower class people of twenty thousand acres. This grant was allotted to the peoples of lower among Christians, Hindus and Muslims.

In Lower Bari Doab Colony British's priorities were to meet military and political requirements merge with agricultural improvements. It was clear that British government wanted in shape of agricultural colonization to fulfil their military and political interests of the Imperialist rule. Government granting land to the landed gentry, ex-military men and influential socio-economic or religious dominated class infect British strengthened social and political structure of their Imperial rule.

\section{Nili Bar Colony}

Nili Bar Colony was the direct outcome of the Sutlej Valley Project. Sutlej river already had inundation canal from both sides but these 
canal have no proper weirs at their heads and also have no means of controlling the volumes of water entering them. The two main objectives of this project was to establish proper weirs at their heads and means of controlling the volume of water. Secondly, to excavate four new canal from the river Sutlej namely Pakpattan, Dipalpur, Eastern and Mailsi. (Administration Report of the Canals in the Punjab, 1928-29) This whole project was completed in In 1933. It was estimated that whole project irrigated 59.5 lakhs acres, 28 lakh acres in the Punjab the same in the Bahawal pur state and 3.5 lakh acres in the Bikaner state. (Administration Report of the Punjab and its Dependences, 1921-22) Major allotment of land in perennial and non-perennial canal in Nilli Bar Colony is shown in the following table;

Allotment of land in Nilli Bar Colony

\begin{tabular}{|l|l|l|l|}
\hline Sr. & Name of Grants & $\begin{array}{l}\text { Area in } \\
\text { acres }\end{array}$ & Percent \\
\hline \multicolumn{3}{|l|}{ Perennial canal irrigation } \\
\hline i & Peasant grants & 250,750 & 31.17 \\
\hline ii & Land for auction & 362,250 & 45.02 \\
\hline Iii & Reward grants Non-perennial & 0.62 \\
\hline Iv & Police grants canals \\
\hline \multicolumn{4}{|l|}{} \\
irrigation & 36,750 & 4.57 \\
\hline i & Janglis & 5,000 & 830,400 \\
\hline ii & Forests & 30,000 & 11.52 \\
\hline
\end{tabular}

Source: Punjab Revenue and Agriculture Proceedings (Revenue) July 1927

A major portion of Land allotment in perennial canal irrigation was reserved for both civilian peasant and open auction. It was more than 76 percent area of the total perennial canal irrigation land in Nili Bar Colony. It was the most important feature of this colony. Further 230,400 acres' land which is 88.48 percent of the non-perennial irrigation land was reserved for jangli (native people) of the Multan and Montgomery (present Sahiwal) districts of the Punjab province. It was the most important feature of the Nili Bar Colony that more than 88 percent area of the perennial canals were reserved for the local people. This policy of the British government played positive role for the local people to change their social and economic 
position. It also helps out to develop a new landed and agriculture class in the local community of the Multan and Montgomery district. (Punjab Revenue and Agriculture Proceedings, 1929-30) In contrast the horse breeding, military and development grants were not the part of Nili Bar Colony, which were the Major part of the Lower Bari doab and Jehlum Colony.

For the development of agriculture sector a sizeable portion was reserved for sugarcane cultivation and for the graduate of Lyallpur Agriculture College. British Government fixed twenty-one thousand acres, land for the development of livestock in Nili Bar Colony. In this scheme two cattle farms were established for cattle breeding each farm had three thousand acres. The remaining lands were allotted to the civilian farmers at cattle breeding terms. This was another positive initiate by the government to improve the socio economic condition of the people of Multan and its adjoin districts. (Board of Revenue of the Nili Bar Colony, 1925)

The British government also had their political objectives to achieved through these canal colonies therefore, government used lands of these canal colonies for their political purpose. Some portion of peasants' grant were reserved for the land holding people of the Punjab. Political objectives of the British government were also prominent in case of the Reward grants, Police and Criminal Tribes grants. Rewards grants were mostly allotted to those nonofficial people of the area who has rendered their loyalty and cooperation to the British government. These types of grants for the same purpose had been used in the previous canal colonies. (Ali, 1989) Nili Bar Colony was the last phase of colonization process of the British government in the Punjab province. It was new model of agricultural economy and political objectives of the British in India during the twentieth century. British had introduced a new administrative and political model in British India. In Punjab British government introduced controlled political franchise system in their new political model of governance. In this new model of ruling British used landed and religious elites for their political objectives. In result of that landed elites and powerful religious families (guardians of the shrines families) of the Punjab province play 
important role in political and administrative system of the British Punjab. The land owners of the south western region of the Punjab province had great socio economic and political power because they had their influence in local community of the region. Because land was the major source of individual izzat (honour) in society. The British exercise political system were based upon limited franchise and government also implement new administrative and political model in which landed elite had great power. Therefore, the landed elites of the British Multan played important role such as Qureshi, Gillani, Laghari, Khosa, Daha, Hiraj and Doultana families. The Unionist Party was the group of landed and religious elites of the province. Most of these political families were the part of Unionist Party in Punjab from 1923-1945. When this landed aristocracy change their political support or affiliation from Unionist Party, then Muslim League replace it in the politics of the Punjab province. (akhter, 2016) Most of the leading rural families had developed good relation with the British during colonial rule in Punjab. Therefore, British realized the importance of these rural landed elite and made many laws to protect them.

The Punjab Alienation of Land Act of 1901, this act stopped land transfer towards moneylenders and non-landed owners' families. This act further divided the rural society of province into an agriculture and non-agriculture groups. This act provided an important stimulus to future co-cooperation between the British and rural landed elites. The second initiative taken by the British government was the Court of Wards Administration of 1903, after implementing the Court of Wards Administration the British government supervised many leading estates of the rural landed elites either as result of their loan defaulter or of their inheritance matters. (Darling, 1977) The British also made very favorable recruitment policy for the agriculture class. The British Government set up a commission in 1918 under the chairmanship of H.J. Maynard to consider the recruit policy about the agriculture class. The recommendation of this commission was considered and implemented by the Michel O, Dwyer in the Punjab province. (Punjab Legislative Council Debates, 12 March1925) The British also made friendly modern educational policy for the landed elites of the province Aitchison College (1886) is one the important 
example where only the sons of leading landed elites can get admission for education. Many old students of this college had played dynamic role in the politics of the Punjab Province. Malik Khizar Hayat Tiwana is one of them. The British awarded honorary ranks and titles and administrative positions to the local landed aristocracy. In local government and in Punjab Legislative Assembly government also nominated the people from the landed elites. Lastly the British Government reserved land in reward grants in all canal colonies. This grant was mostly allotted to the tribes (people or families) to get their loyal services and cooperation in their respective areas for the British.

\section{Conclusion}

The British government introduced many socio-economic and political reforms/developments in Punjab province, the most important development was the canal colonies. The British had some main objectives behind the Canal Colonies. Firstly, they were wanted to collect more revenue from agriculture sector, therefore, British introduced excellent canal irrigation system in Punjab specially in the south western part of the province. Secondly They realized that they had to base their political control on the support of the leading landed elites of the south part of the province. This is why British allotted the land of the canal colonies in a different categories and used it for their own political interest. Thirdly, The British Government used land (specially land of the canal colonies) for both economy and military efficiency. Because The Indian Army was most important to British Rule in sub-continent to maintain law and order and to strengthened British influence in Middle East.

The British engineered excellent nine major canal colonies system in the Punjab province. These canals irrigated more than twenty-six million acres' land in Punjab and specially the Six Million acres' land of the south western part of the province. Thus this excellent canal colonies irrigation system transformed into the richest agriculture area in the sub-continent. These Canal Colonies provided vast opportunity for economic progress, which motivated the rural community towards political and social context. South region became the center of human settlement and trade. Agriculture 
production was marketed in different parts of the sub-continent and some agriculture items were also exported in other countries. Canal Colonies also proved financially profitable for the British. A large share of land in the canal colonies were fixed for the military purposes in different categories. This policy of the British government motived at large number of Punjabi people to recruit in the British Indian Army. Landed elites were the other group that received a heavy allotment of land. The benefits that the landed gentry gets from the canal colonies provided a sound economic basis for their continued loyalty and cooperation to the British. These people get unfair power in the postcolonial period and have exercised their power in Pakistani politics. These people successfully defend the interests of their class to implement land reforms and agriculture tax in Pakistan. 


\section{References}

1. Administration Report of the Canals in the Punjab, (1928-29).

2. Administration Report of the P.W.D (irrigation branch), (1938-39). Delhi.

3. Administration Report of the Punjab and its Dependences, (1921-22).

4. akhter, s. (2016). Politicla Developments and the Role of Notables in Colonial Multan,1990-1947. Islamabad;National Institute od Historical and CulturalRearch.

5. Ali, I. (1979). The Punjab Canal Colonies, 1885-1940. Canbeera;university.

6. Ali, I. (1989). The Punjab Canal Colonies,1885-1940, Delhi;Oxford university Press.

7. Board of Revenue of the Nili Bar Colony, (1925). La hore.

8. Darling,M., (1977). The Punjab Peasant in Prosperityand Debit, New Delhi

9. Himadri Banerjee, (1982). Agrarian Society of the Punjab,1901-1940, New Delhi.

10. Punjab Legislative Council Debates, (12 March 1925). Lahore.

11. Punjab Revenue and Agriculture Proceedings, (1929-30).Lahore.

12. Sa ini,B.S., (1975). The Social and Economic History of the Punjab 19011939. Delhi: ESS ESS Publications. Wace F.B., (1934). The Punjab Colony Manual, Lahore; Superintendent Government printing press.

13. Yadav,Kripal C., (1987). Elections in Punjab,1920-1947. New Delhi: Manohar Publications. 